\title{
CHRONOLOGY OF THE OBI-RAKHMAT GROTTO (UZBEKISTAN): FIRST RESULTS ON THE DATING AND PROBLEMS OF THE PALEOLITHIC KEY SITE IN CENTRAL ASIA
}

\author{
Andrei I Krivoshapkin ${ }^{1}$ Yaroslav V Kuzmin ${ }^{2}$ A J Timothy Jull ${ }^{3}$ \\ ABSTRACT. The Obi-Rakhmat Grotto is one of the key Paleolithic sites in Central Asia. Archaeological excavations have \\ revealed 22 strata containing archaeological materials. Lithic assemblages from all cultural layers display features similar to \\ both late Middle Paleolithic blade industries and early Upper Paleolithic complexes in Southwest Asia and the Siberian Altai \\ Mountains; this suggests a gradual Middle-to-Upper Paleolithic transition occurred in western Central Asia. Hominid remains \\ found at Obi-Rakhmat (layer 16) show a mixture of archaic and modern traits. Different chronometric methods (radiocarbon, \\ optically stimulated luminescence [OSL], U-series, and electron spin resonance [ESR]) were applied to the site's deposits. It \\ appears that ${ }^{14} \mathrm{C}$ dates are more reliable in terms of correspondence to the general framework of the Paleolithic of Central Asia \\ and neighboring regions, and after critical analysis and the deletion of outliers, the upper part of the site's cultural sequence \\ can be dated between 36,000-41,400 BP (layer 7) and 48,800 BP (layer 14.1). The U-series dating results are less secure due \\ to the high uranium content and the presence of detritus, which contaminates dated sediments (travertine). The OSL dating \\ gave uniform ages for all cultural succession ( $\sim 8 \mathrm{~m}$ of deposits), and confirms a very rapid sedimentation rate. Results of ESR \\ dating depend greatly on the choice of uptake model. Dates calculated for the early uptake to some extent correspond to ${ }^{14} \mathrm{C}$ \\ data. The linear uptake chosen by Skinner et al. (2007) makes sediments very old (about 55,000-90,000 yr ago), which con- \\ tradicts ${ }^{14} \mathrm{C}$ dates and does not correspond well to the regional archaeological context.
}

\section{INTRODUCTION}

The chronology of Paleolithic complexes in Central Asia was until recently in its infancy stage, with few radiometric age determinations available (see reviews: Ranov and Davis 1979; Vishnyatsky 1999). Only in the last few years has more information about the timing of the Middle and Upper Paleolithic sites in the republics of Tajikistan and Uzbekistan come to light (Trinkaus et al. 2000; Derevianko et al. 2001; Ranov et al. 2002). The Obi-Rakhmat Grotto in the Republic of Uzbekistan (Figure 1) was first studied in the 1960-70s (see Derevianko et al. 2001), but no reliable chronometric data were obtained. A new stage of research began in 1998 when excavations with tight stratigraphic control and multidisciplinary approach were initiated. As a result, the role of Obi-Rakhmat stone industries in understanding the regional Paleolithic cultural evolution significantly increased. At present, the Obi-Rakhmat has become one of the key Paleolithic sites in all Central Asia. What make this site very important for Old World archaeology is the Paleolithic human fossils found in 2003. Human remains are associated with an archaeological complex showing a Middle-to-Upper Paleolithic transition in technological and typological features (cultural stratum 16). The remains express a mixture of morphological traits typical for Neanderthals and modern humans (Glantz et al. 2008:235). Teeth morphology testifies in favor of the Neanderthal affinity (Bailey et al. 2008), while the observable morphology of cranial remains is much closer to modern humans. Thus, determining the exact age for the main cultural components of the Obi-Rakhmat is important task.

\section{MATERIAL AND METHODS}

The Obi-Rakhmat Grotto $\left(41^{\circ} 34^{\prime} 08.8^{\prime \prime} \mathrm{N}, 70^{\circ} 08^{\prime} 00.3^{\prime \prime} \mathrm{E}\right.$; $1250 \mathrm{~m}$ asl) is located about $100 \mathrm{~km}$ northeast of the city of Tashkent, in the piedmont zone of the western Tien Shan Mountains (Figure 1).

\footnotetext{
${ }^{1}$ Institute of Archaeology \& Ethnography, Siberian Branch of the Russian Academy of Sciences, Lavrentiev Ave. 17, Novosibirsk 630090, Russia. Corresponding author. Email: shapkin@archaeology.nsc.ru.

${ }^{2}$ Institute of Geology \& Mineralogy, Siberian Branch of the Russian Academy of Sciences, Koptyug Ave. 3, Novosibirsk 630090, Russia.

${ }^{3}$ Arizona AMS Laboratory, University of Arizona, Tucson, Arizona 85721-0081, USA.
}

(C) 2010 by the Arizona Board of Regents on behalf of the University of Arizona

Proceedings of the 20th International Radiocarbon Conference, edited by A J T Jull

RADIOCARBON, Vol 52, Nr 2-3, 2010, p 549-554 


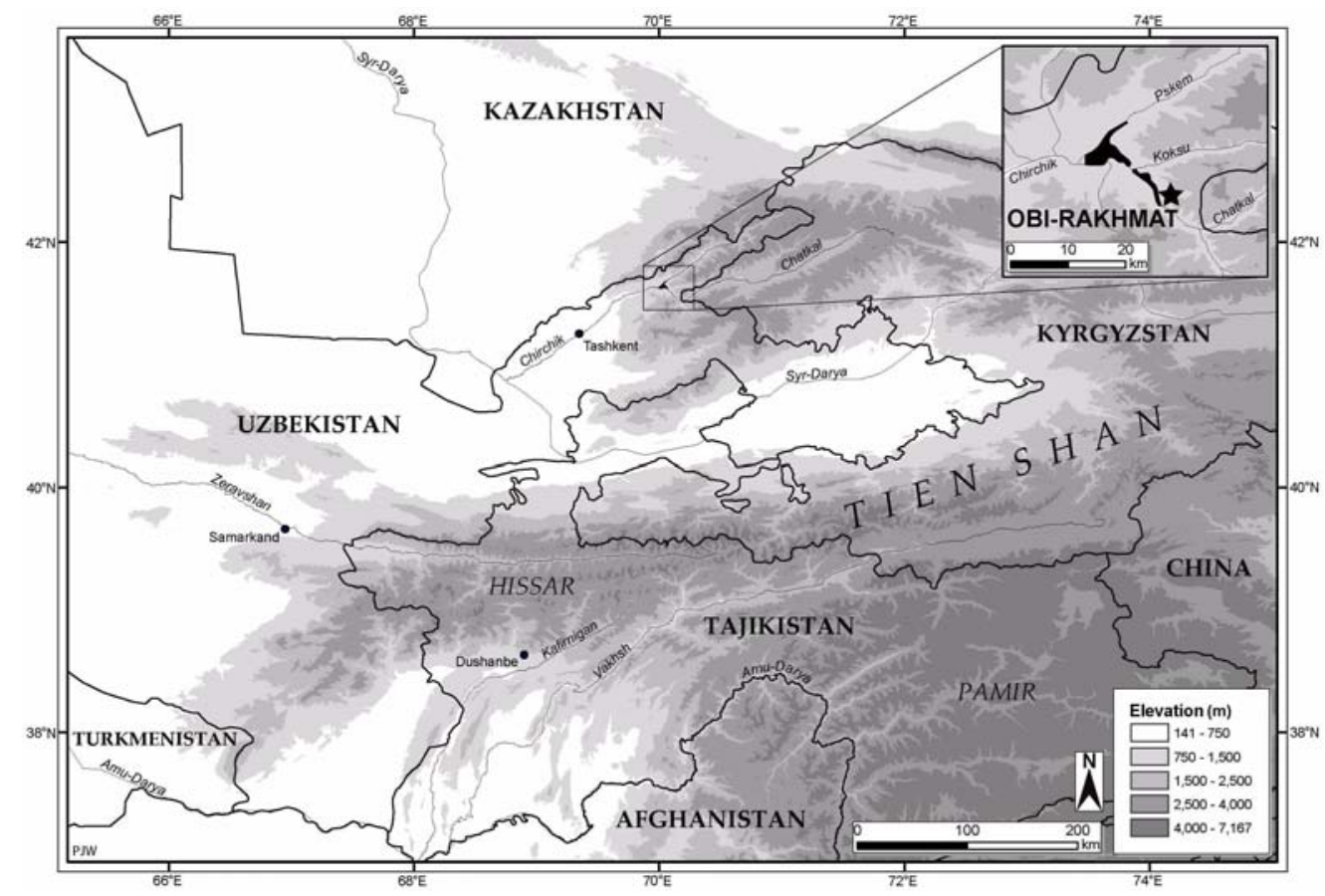

Figure 1 Location of the Obi-Rakhmat Grotto in Central Asia

The grotto is a wide and high limestone rockshelter that opens to the south, The base of the 11-mdeep uninterrupted stratigraphic sequence represents a karstic setting with intermittent and lowenergy deposition of autochthonous debris and anthropogenic material (layers 15-22 in Derevianko et al. 2001). These deposits were later affected by episodic waterlogging. The whole sequence overlying the layers of karst origin comprises a continuous series of freshwater low-energy spring deposits containing weakly reworked cultural material that was buried with calcium carbonate deposition (layers 4-14, see Figure 2). The appearance of a spring did not cause humans to abandon the rockshelter, and they continued to occupy it (Mallol et al. 2009).

As for cultural affiliation of the Obi-Rakhmat lithic assemblages, there are 2 major viewpoints. Derevianko (2001:94-5; Derevianko et al. 2001) and Krivoshapkin et al. (2006) consider the complete cultural sequence as a gradual transition from the Middle to Upper Paleolithic, while Vishnyatsky (2004a,b) suggests that all the site's archaeological complexes represent a blade variant from the late Middle Paleolithic. The discussion about the affiliation of the Obi-Rakhmat stone industry is ongoing (e.g. Glantz et al. 2008:225). Based on material from the most recent excavations (2007-9), the transitional Middle-to-Upper Paleolithic appearance of Obi-Rakhmat industry looks more reasonable (Krivoshapkin, in press). Lithic assemblages of the Obi-Rakhmat site display many features similar to both late Middle Paleolithic blade industries and early Upper Paleolithic assemblages in Southwest Asia (Levant and neighboring regions) and the Altai Mountains of Siberia (e.g. Derevianko 2001; Derevianko et al. 2001, 2004; Krivoshapkin et al. 2006).

For chronological study of the cultural layers at Obi-Rakhmat site, several dating methods were employed including radiocarbon $\left({ }^{14} \mathrm{C}\right)$, uranium-series (U-series), optically stimulated luminescence (OSL), and electron spin resonance (ESR). ${ }^{14} \mathrm{C}$ dating was performed by routine acid-baseacid (ABA) pretreatment of small charcoal specimens following $\mathrm{CO}_{2}$ gas preparation, graphitiza- 


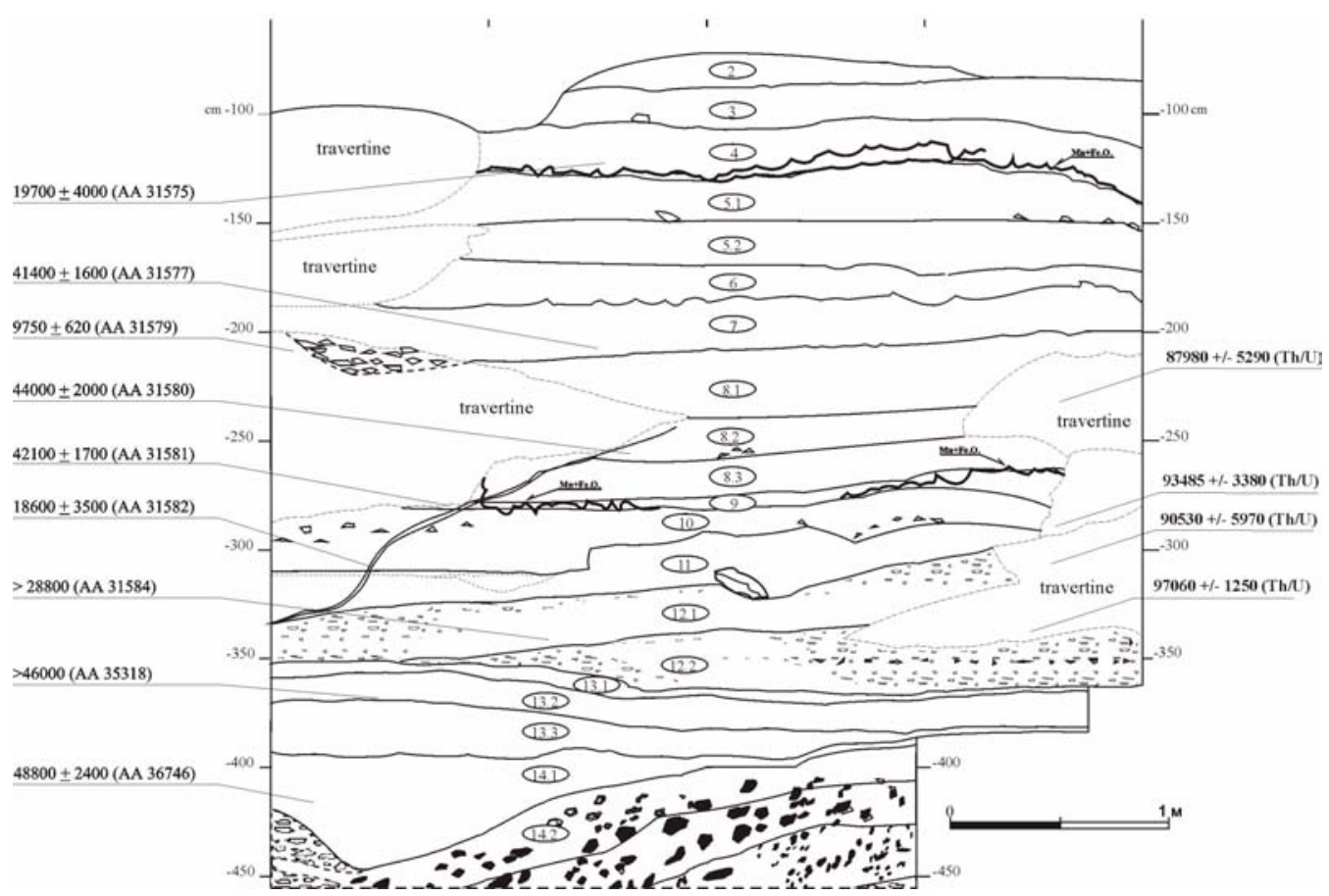

Figure 2 Section of the upper part of the northern wall at Obi-Rakhmat Grotto with radiometric dates [left column: ${ }^{14} \mathrm{C}$ dates; right column: U-series dates, see Wrinn et al. (2004)]. The length of grids on the top is $1 \mathrm{~m}$; layer numbers are in ovals; depth on vertical axis is the distance in cm below the datum.

tion, and ${ }^{14} \mathrm{C}$ measurement at the Arizona AMS Laboratory (e.g. Jull et al. 2003). The methodology of U-series dating is described in Wrinn et al. (2004). The details of ESR dating are given in Skinner et al. (2007). The OSL dating was performed by Dr J K Feathers at the Luminescence Dating Laboratory, University of Washington. Sediment chunks were collected from strata 5-21, and finegrained polymineral material was dated. The details of OSL dating will be published elsewhere.

\section{RESULTS AND DISCUSSION}

${ }^{14} \mathrm{C}$ dating results for cultural strata $4-14$ are given in Table 1 . As one can see, there are several definite outliers that do not fit site's stratigraphy: AA-31579, -57040 , and -31582. The reasons for age inversions are unknown, and the best we can do at this stage is to reject them. A similar situation with large discrepancies in ${ }^{14} \mathrm{C}$ AMS date series was observed at another Paleolithic key site in Central Asia, Ogzi-Kichik (Ranov et al. 2002:14-5). The same feature was detected at some well-excavated cave sites in central Europe (e.g. Conard and Bolus 2008). Also, samples AA-31575, -31580, and -31582 have a large standard deviation, and this makes them less reliable (also see below). The "open” value of sample AA-31584 does not add much to our knowledge, but because it does not contradict the general chronological framework, we accepted it.

Evaluation of some outlier/rejected samples shows the following. The AA-31575 specimen was $0.37 \mathrm{mg}$ in weight, with a carbon yield of only $6.1 \%$, much less than usual for charcoal ( $40-50 \%$ or so). The amount of carbon dated was extremely small, $0.023 \mathrm{mg}(23 \mu \mathrm{g})$. Due to its ambiguous composition and very small size, we rejected this value. The AA-31579 sample (thought to be charcoal) yielded only $2.75 \%$ of carbon ( $75 \mu \mathrm{g}$ in weight), which is a very low number, and because of this and 
Table 1 Results of ${ }^{14} \mathrm{C}$ dating of the charcoal samples from Obi-Rakhmat site (layers 4-14).

\begin{tabular}{|c|c|c|c|c|c|c|}
\hline Year & Layer & $\begin{array}{l}\text { Depth } \\
\text { (cm) }\end{array}$ & $\begin{array}{l}{ }^{14} \mathrm{C} \text { date } \\
(\mathrm{BP})\end{array}$ & Lab nr & $\begin{array}{l}\delta^{13} \mathrm{C} \\
(\%)\end{array}$ & Comment \\
\hline 1999 & 4 & 121 & $19,700 \pm 4000$ & AA-31575 & -24.2 & Very small size and low C yield; rejected \\
\hline 2003 & 7 & 195 & $36,170 \pm 810$ & AA-57114 & -24.9 & Accepted \\
\hline 1999 & 7 & 201 & $41,400 \pm 1600$ & AA-31577 & -24.0 & Accepted \\
\hline 1999 & 8.1 & 231 & $9750 \pm 620$ & AA-31579 & -22.7 & Low $\mathrm{C}$ yield and outlier; rejected \\
\hline 1999 & 8.2 & 254 & $44,000 \pm 2000$ & AA-31580 & -23.5 & Accepted \\
\hline 2003 & 8.2 & 254 & $29,300 \pm 350$ & AA- 57040 & -24.0 & Outlier; rejected \\
\hline 1999 & 9 & 304 & $42,100 \pm 1700$ & AA-31581 & -24.4 & Accepted \\
\hline 1999 & 10 & 332 & $18,600 \pm 3500$ & AA-31582 & -27.0 & $\begin{array}{l}\text { Low C yield, unusual appearance, outlier; } \\
\text { rejected }\end{array}$ \\
\hline 1999 & 12.1 & 336 & $>28,800$ & AA-31584 & -23.4 & Accepted \\
\hline 2000 & 13.2 & 387 & $>46,000$ & AA-35318 & -23.8 & Accepted \\
\hline 2000 & 14.1 & 420 & $48,800 \pm 2400$ & AA-36746 & -23.4 & Accepted \\
\hline
\end{tabular}

its inconsistency with the site's stratigraphy, we rejected it outright. The AA-31582 sample weighed $1.59 \mathrm{mg}$, but it looked not like charcoal but a kind of dirt, and the carbon yield was very low $-0.9 \%$ (15 $\mu \mathrm{g}$ in weight); it was rejected on this ground as well as its reversal in age (Table 1).

In general, based on the results of ${ }^{14} \mathrm{C}$ dating, the age of layer 7 is about $36,000-41,400 \mathrm{BP}$. The ${ }^{14} \mathrm{C}$ values for layers $8.2(44,000 \pm 2000 \mathrm{BP})$ and $9(42,100 \pm 700 \mathrm{BP})$ overlap within $\pm 1 \sigma$; thus, their average age is about 43,000 BP. Layer 14.1 has near the limit of the Arizona AMS machine sensitivity ( 48,000 BP), and it could be even older.

U-series dates were originally published by Wrinn et al. (2004) (see also Figure 2). For cultural layers $5.1,5.2,6$, and 7, the age (with $\pm 2 \sigma$ ) is $87,045 \pm 8300 \mathrm{yr}$; for layers 8.1-8.3: 87,980 $\pm 5290 \mathrm{yr}$; for layers 8.3, 9, 10, and 11: 93,485 $\pm 3380 \mathrm{yr}$; and for layers 12.1-12.2: 90,530 \pm 5970 and 97,060 \pm 1250 yr. However, due to high uranium content and the presence of detritus, which contaminates dated sediments (P J Wrinn, personal communication 2007), the results are highly influenced by these factors and cannot be accepted as reliable due to the limitations of U-series dating (e.g. Latham 2001). Skinner et al. (2007:1238, Figure 2 caption) noted that “230 $\mathrm{Th} / 234 \mathrm{U}$ ages hardly vary with depth.”

The preliminary results of OSL dating of Obi-Rakhmat sediments produced statistically overlapping values for layers 5.1 (56,000 $\pm 3200 \mathrm{yr}), 8.1(60,100 \pm 3000 \mathrm{yr})$, and $21.2(61,400 \pm 3600 \mathrm{yr})$; these values are highly influenced by the presumable moisture content and probable increase/decrease in the effective dose rate from ${ }^{40} \mathrm{~K}$ through time (J K Feathers, personal communications 2006, 2007). This might mean that sedimentation in the rockshelter took place very rapidly, although essentially the same age for $8 \mathrm{~m}$ of deposits (Derevianko et al. 2004) can suggest that the OSL data have thus far very limited merit for understanding the chronology of Obi-Rakhmat site.

The situation with ESR dates seems to be complicated and not as straightforward as suggested earlier. Skinner et al. (2007) assumed a linear uptake (LU) in the uranium model, arguing that results of Useries dating and isochron analyses are in favor of it and because the LU model normally gives more reliable ages in comparison tests against other dating methods for sites between 50,000 and 100,000 yr ago (Skinner et al. 2007). The main conclusion about the age of layers 12 ( 56,900 yr ago), 13 ( 65,500 yr ago), and 21 ( 87,000 yr ago) (Skinner et al. 2007) contradicts the ${ }^{14} \mathrm{C}$ data (Table 1 ).

However, according to Skinner et al. (2007:1240) “...high U concentrations also mean that the U uptake model significantly affects the calculated ages and, therefore, choosing the correct U uptake 
model becomes important...”. So, if we assume based on available ${ }^{14} \mathrm{C}$ data that the Obi-Rakhmat cultural sequence (at least down to layer 15) is younger than 50,000 yr ago, then the early uptake (EU) uranium model can be applied to the Obi-Rakhmat ESR dates, and results look much more reasonable. Layer 13 would be $~ 36,700$ yr old; the age of layer 21.2 would be $~ 50,200$ yr (Skinner et al. 2007:1241, Table 4). As already mentioned, this is in general accord with ${ }^{14} \mathrm{C}$ data (Table 1). If we can "calibrate" (sensu Weninger and Jöris 2008; but see van der Plicht et al. 2004) the ${ }^{14} \mathrm{C}$ values older than $\sim 20,000 \mathrm{BP}$, the estimate for layer $14.1\left({ }^{14} \mathrm{C}\right.$ date of $\left.48,800 \pm 2400 \mathrm{BP}\right)$ would be $53,774 \pm$ 3944 cal $\mathrm{BP}_{\text {Hulu }}$ (see CalPal-2007 ${ }_{\text {Hulu }}$ online: www.calpal-online.de; Weninger and Jöris 2008). Unfortunately, this is still beyond the limit of the new IntCal09 calibration curve (Reimer et al. 2009). Disagreements between results of ${ }^{14} \mathrm{C}$, luminescence, and ESR dates were observed at several well-studied European sites (e.g. Richter et al. 2000, 2009; Hoffecker et al. 2008), and more careful study is necessary to resolve the large difference between ${ }^{14} \mathrm{C}$ and other dating methods at the Obi-Rakhmat.

As for issue of the age of Obi-Rakhmat sequence being possibly beyond the limit of sensitivity of ${ }^{14} \mathrm{C}$ dating method (see Derevianko et al. 2004:202), we can say now that at least layer 9, dated to $\sim 42,100 \mathrm{BP}$, is well within the limit of ${ }^{14} \mathrm{C}$ age detection. Possibly, the age of layer $14.1(\sim 48,800$ BP) may be a minimal estimate, but more study is necessary to precisely determine the age. Thus, the question about the true age of layer 14 at Obi-Rakhmat site is still open to discussion, but there is no "discrepancy" between the ${ }^{14} \mathrm{C}$ and U-series dates (see Skinner et al. 2007:1237).

\section{CONCLUSION}

Critical evaluation of the Obi-Rakhmat Grotto ${ }^{14} \mathrm{C}$ record and its comparison with results of other dating methods allowed us to conclude that the age of the upper part of Obi-Rakhmat sequence is about 36,000-49,000 BP, while its base could be older and beyond the ${ }^{14} \mathrm{C}$ limit. Under any circumstances, keeping in mind artifact homogeneity of the Obi-Rakhmat complexes and the general regional cultural context, the age of the lowest archaeological horizons (layers 15-22) cannot be much older than those for layers $4-14$. The ${ }^{14} \mathrm{C}$ results generally fit the early uptake model of ESR dating, while the liner uptake model makes ages unreasonably old. The OSL and U-series data have thus far not given rational age estimates. More work needs to be done in the near future to secure the preliminary chronology of the Obi-Rakhmat. Additional analysis and pretreatment of charcoal using recent developments (e.g. Brock and Higham 2009) would be very helpful.

\section{ACKNOWLEDGMENTS}

We are grateful to Dr James K Feathers (University of Washington, Seattle, Washington, USA) for providing us the unpublished results of OSL dating of the Obi-Rakhmat site. Assistance with sampling and generating funds for dating program at the Obi-Rakhmat was given by Mr Patrick J Wrinn (University of Arizona, Tucson, Arizona, USA). The ${ }^{14} \mathrm{C}$ dating was supported by the US National Science Foundation (EAR 97-30699 and 01-154881), and L S B Leakey Foundation. Mr Richard J Cruz (Arizona AMS Laboratory) provided additional information for ${ }^{14} \mathrm{C}$-dated samples.

\section{REFERENCES}

Bailey S, Glantz M, Weaver TD, Viola B. 2008. The affinity of the dental remains from Obi-Rakhmat Grotto, Uzbekistan. Journal of Human Evolution 55(2):23848.

Brock F, Higham TFG. 2009. AMS radiocarbon dating of Paleolithic-aged charcoal from Europe and the Medi- terranean Rim using ABOx-SC. Radiocarbon 51(2): 839-46.

Conard NJ, Bolus M. 2008. Radiocarbon dating the late Middle Paleolithic and Aurignacian of the Swabian Jura. Journal of Human Evolution 55(5):886-97.

Derevianko AP. 2001. The Middle to Upper Paleolithic 
transition in the Altai (Mongolia and Siberia). Archaeology, Ethnology \& Anthropology of Eurasia 3(7):70103.

Derevianko AP, Krivoshapkin AI, Anoikin AA, Islamov UI, Petrin VT, Saifullaiev BK, Suleimanov RH. 2001. The Initial Upper Palaeolithic of Uzbekistan: the lithic industry of Obi-Rakhmat Grotto (on the basis of materials recovered from strata 2-14). Archaeology, Ethnology \& Anthropology of Eurasia 4(8):42-63.

Derevianko AP, Krivoshapkin AI, Anoikin AA, Wrinn PJ, Islamov UI. 2004. The lithic industry of Obi-Rakhmat Grotto. In: Derevianko AP, editor. Grot ObiRakhmat. Novosibirsk: Institute of Archaeology \& Ethnography Press. p 5-33. In Russian and English.

Glantz M, Viola B, Wrinn P, Chikisheva T, Derevianko A, Krivoshapkin A, Islamov U, Suleimanov R, Ritzman T. 2008. New hominin remains from Uzbekistan. Journal of Human Evolution 55(2):223-37.

Hoffecker JF, Holliday VT, Anikovich MV, Sinitsyn AA, Popov VV, Lisitsyn SN, Levkovskaya GM, Pospelova GA, Forman SL, Giaccio B. 2008. From the Bay of Naples to the River Don: the Campanian Ignimbrite eruption and the Middle to Upper Paleolithic transition in Eastern Europe. Journal of Human Evolution 55(5):858-70.

Jull AJT, Burr GS, Beck JW, Donahue DJ, Biddulph D, Hatheway AL, Lange TE, McHargue LR. 2003. Accelerator mass spectrometry at Arizona: geochronology of the climate record and connections with the ocean. Journal of Environmental Radioactivity 69(12):3-19.

Krivoshapkin AI. In press. Microblade and bladelet technology in Central Asia: new evidences from Obi-Rakhmat (Uzbekistan). Archaeology, Ethnology \& Anthropology of Eurasia.

Krivoshapkin AI, Anoikin AA, Brantingham PJ. 2006. The lithic industry of Obi-Rakhmat Grotto, Uzbekistan. Bulletin of the Indo-Pacific Prehistory Association 26:5-19.

Latham AG. 2001. Uranium-series dating. In: Brothwell DR, Pollard AM, editors. Handbook of Archaeological Sciences. Chichester: John Wiley \& Sons. p 63-72.

Mallol C, Mentzer SM, Wrinn PJ. 2009. A micromorphological and mineralogical study of site formation processes at Obi-Rakhmat Grotto, Uzbekistan. Geoarchaeology 24(5):548-75.

Ranov VA, Davis RS. 1979. Toward a new outline of the Soviet Central Asian Paleolithic. Current Anthropology 20(2):249-70.

Ranov VA, Laukhin SA, van der Plicht J. 2002. The first series of radiocarbon dates from the Mousterian sites in Tajikistan. Rossiiskaya Arkheologiya 2:5-16. In Russian with English abstract.

Reimer PJ, Baillie MGL, Bard E, Bayliss A, Beck JW, Blackwell PG, Bronk Ramsey C, Buck CE, Burr GS, Edwards RL, Friedrich M, Grootes PM, Guilderson
TP, Hajdas I, Heaton TJ, Hogg AG, Hughen KA, Kaiser KF, Kromer B, McCormac FG, Manning SW, Reimer RW, Richards DA, Southon JR, Talamo S, Turney CSM, van der Plicht J, Weyhenmeyer CE. IntCal09 and Marine09 radiocarbon age calibration curves, 0-50,000 years cal BP. Radiocarbon 51(4): 1111-50.

Richter D, Waiblinger J, Rink WJ, Wagner GA. 2000. Thermoluminescence, electron spin resonance and ${ }^{14} \mathrm{C}$-dating of the late Middle and early Upper Palaeolithic site of Geißenklösterle Cave in southern Germany. Journal of Archaeological Science 27(1):7189.

Richter D, Tolstevin G, Škrdla P, Davies W. 2009. New radiometric ages for the Early Upper Palaeolithic type locality of Brno-Bohunice (Czech Republic): comparison of OSL, IRSL, TL and ${ }^{14} \mathrm{C}$ dating results. Journal of Archaeological Science 36(3):708-20.

Skinner AR, Blackwell BAB, Mian A, Baboumian SM, Blickstein JIB, Wrinn PJ, Krivoshapkin AI, Derevianko AP, Lundburg JA. 2007. ESR analyses on tooth enamel from the Paleolithic layers at the Obi-Rakhmat hominid site, Uzbekistan: tackling a dating controversy. Radiation Measurements 42(6-7):1237-42.

Trinkaus E, Ranov VA, Laukhin SA. 2000. Middle Paleolithic human deciduous incisor from Khudji, Tajikistan. Journal of Human Evolution 38(4):575-83.

van der Plicht J, Beck JW, Bard E, Baillie MGL, Blackwell PG, Buck CE, Friedrich M, Guilderson TP, Hughen KA, Kromer B, McCormac FG, Bronk Ramsey C, Reimer PJ, Reimer RW, Remmele S, Richards DA, Southon JR, Stuiver M, Weyhenmeyer CE. 2004. NotCal04-comparison/calibration ${ }^{14} \mathrm{C}$ records 26 50 cal kyr BP. Radiocarbon 46(3):1225-38.

Vishnyatsky LB. 1999. The Paleolithic of Central Asia. Journal of World Prehistory 13(1):69-122.

Vishnyatsky LB. 2004a. The Middle-Upper Paleolithic interface in former Soviet Central Asia. In: Brantingham PJ, Kuhn SL, Kerry KW, editors. The Early Upper Paleolithic beyond Western Europe. Berkeley: University of California Press. p 151-61.

Vishnyatsky LB. 2004b. Evolutionary ranking of the late Middle and early Upper Paleolithic industries: a trial. Archaeology, Anthropology \& Ethnology of Eurasia 3(19):41-50.

Weninger B, Jöris O. 2008. A ${ }^{14} \mathrm{C}$ age calibration curve for the last $60 \mathrm{ka}$ : the Greenland-Hulu U/Th timescale and its impact on understanding the Middle to Upper Paleolithic transition in Western Eurasia. Journal of Human Evolution 55(5):772-81.

Wrinn PJ, Wagner JDM, Patchett PJ, Slavinski VS. 2004. Radiocarbon and uranium-series dating of Obi-Rakhmat Grotto. In: Derevianko AP, editor. Grot Obi-Rakhmat. Novosibirsk: Institute of Archaeology \& Ethnography Press. p 190-204. In Russian and English. 